\title{
Tropical Peat Swamp Management Options: A Case Study Using System Dynamic in Southern Aceh
}

\author{
Aswandi $^{*}$, Ronggo Sadono ${ }^{2}$, Haryono Supriyo $^{2}$, Hartono $^{3}$ \\ ${ }^{1}$ Graduate School of Gadjah Mada University, Jl. Agro No. 1, Yogyakarta Indonesia 55281 \\ ${ }^{2}$ Faculty of Forestry, Gadjah Mada University, Jl. Agro No. 1, Yogyakarta Indonesia 55281 \\ ${ }^{3}$ Faculty of Geography, Gadjah Mada University, Jl. Kaliurang, Bulaksumur, Yogyakarta, Indonesia 55281
}

Received October 20, 2015/Accepted November 30, 2015

\begin{abstract}
Tropical peat forest ecosystems have multiple benefits as regulating hydrological system, carbon storage, timber and non-timber products, and protecting the biodiversity. Lack of understanding of these functions, short-term economic benefits is more preferable despite reducing its ecological benefits. This study proposed a system dynamics model of tropical peat forest ecosystem in determining its optimum management for extractive utilizations (timber and nontimberforest products), environmental services, and biodiversity. A dynamics model was used to describe changes in peatland and forest cover, biomass accumulation and carbon storage, and total economic value of tropical peat forest ecosystem in Trumon and Singkil, Southern Aceh. The projection showed that peat forest ecosystem benefits would decline in the long term if degradations continue at the same rate over last decade. Efforts to change the primary peat forest to plantation would reduce the total economic value of ecosystem and biodiversity values at level $-19.63 \%$ and $-26.28 \%$ from current conditions. Carbon emissions were increased at 117.32 ton $\mathrm{CO}_{2}$ eq ha $\mathrm{e}^{-1}$ year ${ }^{-1}$, higher than average of carbon losses from peatland oxidation. Preserving $50 \%$ of forest vegetation on moderate depth and protection very deep peatlands would reduce emission $-6.96 \%$ to $-35.06 \%$ and increase forest carbon storage at significant rate $+15.06 \%$ to $+63.32 \%$, respectively. These mitigation schemes would improve the biodiversity and hydrological function. Forest rehabilitation with agroforestry practices will enhance carbon uptake, especially on degraded lands.
\end{abstract}

Keywords: system dynamics, tropical peatforest, carbon storage, environmental services, total economic value

*Correspondence author, email: andiasw@yahoo.com,ph.: +62-8126209444

\section{Introduction}

Over the last decade, one of ecosystem that became global concern is tropical peat swamp forest. This is related to multi-functionality of these ecosystems in global climate regulation, water resource preservation, reducing floods, supporting of biodiversity, and providing of timber and nontimber for community welfare (Sudip et al. 2005; Blumenfeld et al. 2009; Hooijer et al. 2010; Hirano et al. 2014).

Lack of understanding of these functions lead to the short-term economic benefits was more likely to be considered. During period 2000-2009, approximately 2 million ha tropical peat forest were deforested, the highest in Sumatra which 0.98 million ha due to conversion to oil palm plantations and pulpwood plantations. Until 2009, a total of 10.77 million ha or $51 \%$ of Indonesia's peat forests were degraded (Forest Watch Indonesia 2011). Land conversion and deforestation contributed more than $25 \%$ of total $\mathrm{CO}_{2}$ emissions (Murdiyarso et al. 2013). Carbon losses from peatland degradation reached 65 ton $\mathrm{CO}_{2}$ eq ha ${ }^{-1}$ year ${ }^{-1}$ (Hooijer et al. 2010).

Degradation of peat ecosystem release of greenhouse gases, disrupt hydrological function and loss of biodiversity (Holden et al. 2004; Blumenfeld et al. 2009; Hooijer et al. 2010; Miettinen et al. 2012; Murdiyarso et al. 2013; Hirano et al. 2014; Hommeltenberg et al. 2014). The intensities of floods and thick smoke haze from peatland fire were increased in surrounding degraded peatlands (Holden et al. 2004; Erwin 2008; Basyuni et al. 2015). The level of vulnerability hundreds of flora and fauna species also increased (Wich et al. 2008; Posa 2011). These ecological disasters were estimated trillion rupiah in economic losses annually (Rijksen et al. 1997; Hooijer et al. 2010).

Peat ecosystem function degradation due to the utilization exceeds the carrying capacity. Disturbance of land cover and excessive drainage increase the difficulty of ecosystem recovery. Increased soil acidity, hydrophobic, and irreversible drying characteristics induce low nutrient 
availability, therefore growth of peat forest regeneration is inhibited. Shrubs preclude succession so that restoration efforts take a long time, huge cost, and low extent of success (Page et al. 2008; Wösten et al. 2008). Therefore, based on their marginal and vulnerable characteristics, peat forests management require a proper planning. The principles of equilibrium between utilization and carrying capacity are indispensable.

The objectives of this study was to build a system dynamics model to determine alternatives of peat forest management on timber and non-timber, carbon sequestration, environmental services, and the total economic value of tropical peat forest ecosystem in southern Aceh. The study proposes various alternative policy that support sustainable peat swamp forests management and enhancement of community welfare.

\section{Methods}

Research framework Peat swamp forest is dynamic and complex ecosystem (Blumenfeld et al. 2009; Miettinen et al. 2012; Murdiyarso et al. 2013). A holistic approach is needed to understand the behavior and overcome limitations in estimating the impact of policies. One approach that could be used is system dynamics. This approach helps in understanding the behavior and complexity of ecosystem in spite of limited information (Sterman 2001; Ghaffarzadegan 2011; Mousavi \& Sadeghian 2015). By simulations, dynamics of system interest could predict behavior of the system as a result of a policy or its management scenarios (Sterman 2001; Ghaffarzadegan 2011).

A system dynamics approach in this study is used to describe dynamics of peat forest biomass accumulation, carbon stored, and economic value of timber, non-timber product, and environmental services. System dynamics were constructed to integrate variety of these benefits. Dynamic of peat forest ecosystems were shown in Figure 1. The long term projections were used to determine impact of changes in peatland on multiple benefits of ecosystem. Allocation of peatland forest ecosystem was determined by examining different management scenarios. Optimum allocation was a policy that reduced GHGs emission, increased carbon sequestration, protection of biodiversity and hydrological functions, and increased monetary values of various benefits of these ecosystems.

Research was conducted on peat swamp forest ecosystem on Singkil Watershed in District of Aceh Singkil and South Aceh, Province of Aceh since May 2014 until June 2015. Geographically, it is locate between N2 $15^{\prime} 25^{\prime \prime}-\mathrm{N} 2^{\circ} 43^{\prime} 48^{\prime \prime}$ and E95 $39^{\prime} 22^{\prime \prime}-\mathrm{E} 97^{\circ} 54^{\prime} 48^{\prime \prime}$ in Southern Aceh (Figure 2).The ecosystem that covers an area of 144,512.50 ha represents tropical coastal shallow to deep peat typology and various types of land cover. These is habitat for protected wildlife and endangered species such as the sumatran tiger (Panthera tigris sumatrae), orangutan (Pongo abelii), sumatran elephant (Elephas maximus sumatranus), and the sumatran rhino (Dicerorhinus sumatrensis). Various timber forest products found in peat swamp forests as jelutung (Dyera spp.), meranti (Shorea spp.), rengas (Gluta renghas), medang (Litsea spp.), and others. Non-timber forest products such as honey, tree bark, rattan, and medicinal substance were harvested by local communities. Considering the high conservation value, these area was designated as one of the key biodiversity areas in Sumatra (Conservation International 2007).

Research procedures The research consisted of (a) measurement of changes in peat forest and land cover and carbon dynamics, and (b) development of system dynamics

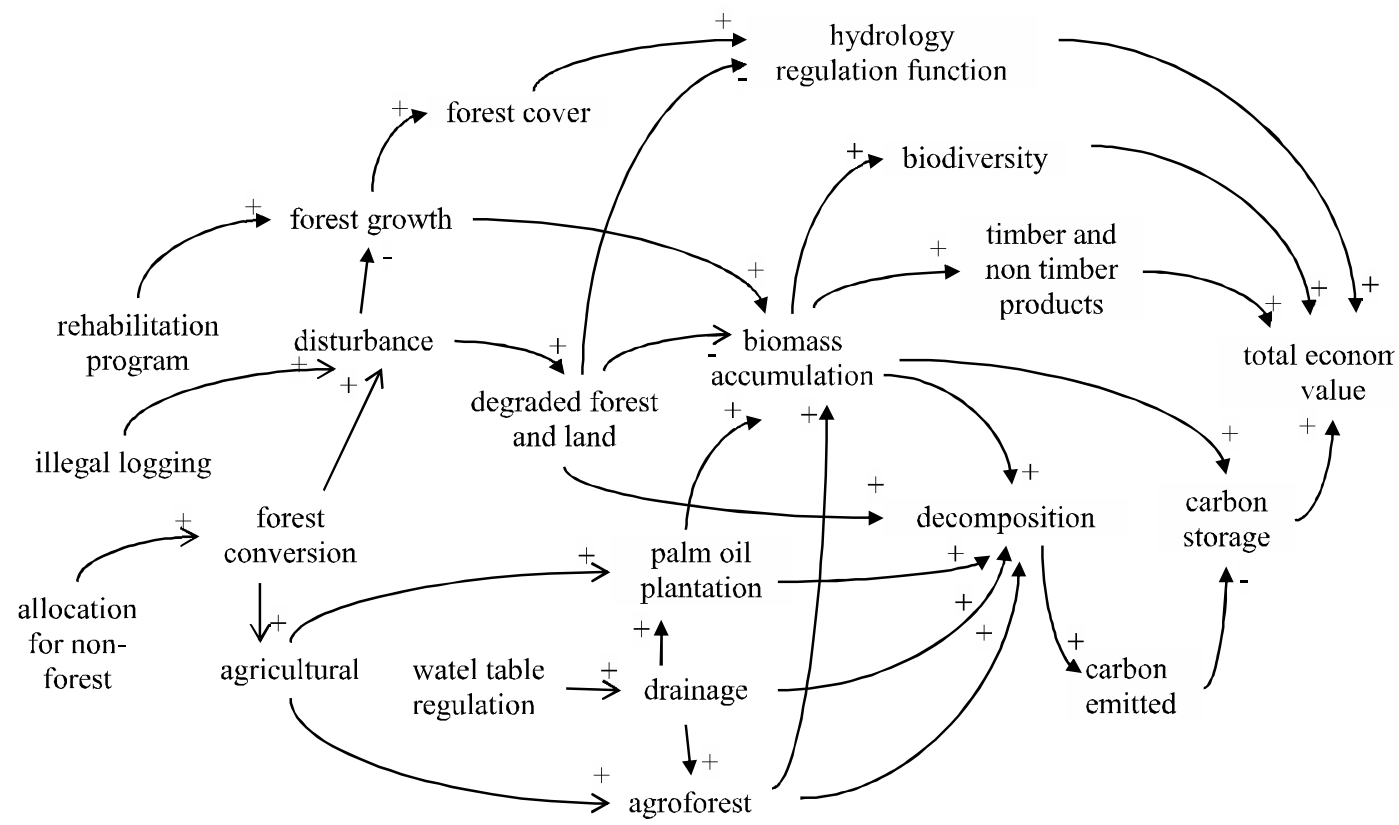

Figure 1 Clausal loop of peat forest ecosystem dynamics. 


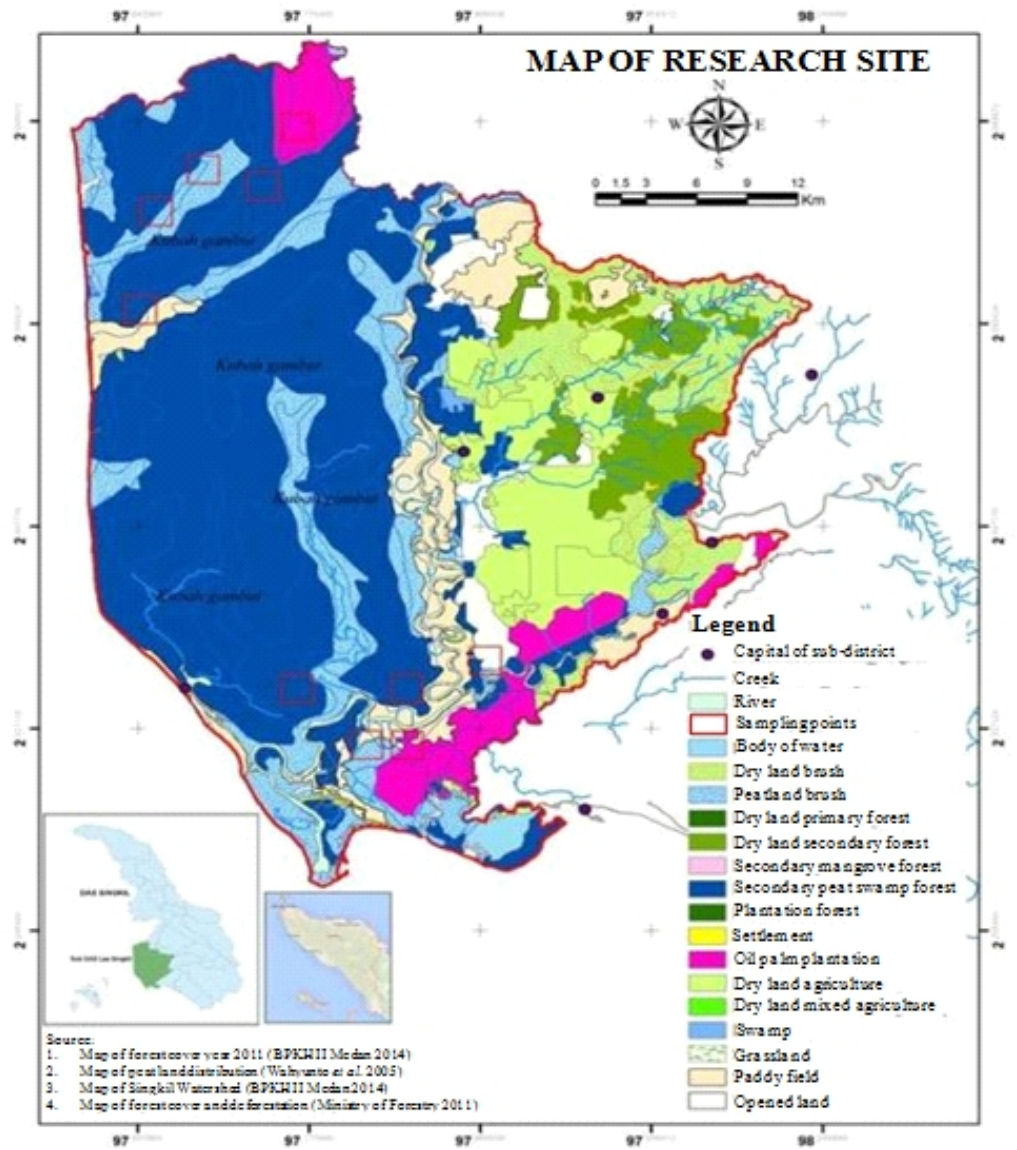

Figure 2 Research site on tropical peat forest ecosystem in Trumon and Singkil, Southern Aceh.

model. Peatland and forest changes were identified using a geographic information system approach based on maps of forest cover in 2003, 2009, 2011 (BPKH II Medan 2014), and maps of peat and forest degradation (Wahyunto et al. 2005; Forest Watch Indonesia 2011). Carbon estimation was conducted using a non-destructive method for 3 carbon pool, i.e. above and below-ground carbon, and soil organic carbon (Kenzo et al. 2009). Some types of peatland cover measured were primary and secondary peat forest, brush, mixed plantation/agroforestry, and oil palm plantations. In each type was built 3 plots $@ 0.25$ ha $(50 \mathrm{~m} \times 50 \mathrm{~m})$. Stand parameters measured were tree diameter and height. Above and below-ground carbon were estimated using allometric equations (Krisnawati et al. 2012). Peatland carbon was calculated based on area of land, peat depth or thickness, bulk density, and C-organic content (Wahyunto et al. 2005). Carbon loss was calculated based on elevated levels of ash (Gronlund et al. 2008; Maswar et al. 2009). Valuation of total economic value of peat ecosystem was conducted on direct use value and indirect use value (Carson 2011). Direct use in form of timber harvesting, non-timber forest products (honeybee, rattan, etc.), the cultivation of agriculture and farming, and fishing were evaluated using market price. While indirect use values of ecosystem as flood control and water provider were evaluated using the avoid damage cost and replacement cost method (Carson 2011). Data collected by structured interview of 30 respondents, i.e. farmers, fishermen, firewood collector, and also community associated with peat swamp forests.

Steps of a system modeling include (a) identification of issues, objectives and constraints, (d) conceptual model formulation, (c) model specification, (d) model evaluation, and (e) use of model (Grant et al. 1997; Purnomo \& Mendoza 2011). The conceptual models were constructed by identifying all components and their relationship with software Stella 9.0.1. Some peat forest cover types measured consist of secondary peat forests, bushes, mixed plantation/agroforestry, oil palm plantations, and primary peat forest. Model were evaluated by observing their rationality and sensitivity and compared with real world or similar reliable models (Grant et al. 1997; Purnomo \& Mendoza 2011). Model was validated by comparing the results of projection with forest cover change in year 2003, 2009, and 2011 (BPKH II Medan 2014). The forest growth based on stand structure dynamic of logged peat swamp forest which consists of ingrowth, upgrowth, mortality, and increment functions (Aswandi 2007).

The model ran by 5 scenarios by varying the driving variables such as the rate of peat forest conversion, the proportion of peat forests can be converted, rate of rehabilitation, and forest growth. The $1^{\text {st }}$ scenario ran at similar condition in the last 12 years. The $2^{\text {nd }}$ scenario were 
executed by converting shallow moderate depth peat into oil palm plantations at rate twice of current conditions. The $3^{\text {rd }}$ and $4^{\text {th }}$ scenario ran by preserving $25 \%$ and $50 \%$ of forest cover, respectively, and convert its remaining to agricultural plantation. The last scenarios ran with moratorium primary peat forest clearance and followed by peat forest rehabilitation with agroforestry development and oil palm plantations. Results of projection were analyzed as policy options.

\section{Results and Discussion}

System dynamics model System dynamics model were constructed based on issues of tropical peat forest resource utilization conflicts, between short-term economic uses with long-term environmental services. The options include timber harvesting, forest conversion into plantation or protect, and optimize its environmental services such as hydrological functions of flood control, carbon storage, and biodiversity habitat (Blumenfeld et al. 2009; Murdiyarso et al. 2013).

Changes in forest cover affect the hydrological function and biomass accumulation (Dommain et al. 2010). Most biomass felled down into litters and decomposed, thereby increasing soil carbon stocks (Hirano et al. 2014). Forest conversion and drainage inflict biomass losses, increase rate of decomposition, and carbon emissions level. Furthermore, biomass losses degrade land productivity and forest products (Dommain et al. 2010; Murdiyarso et al. 2013; Hirano et al. 2014; Hommeltenberg et al. 2014). These changes affect carbon dynamic in the ecosystem. The peat ecosystem benefits were calculated as total economic value of these functions.

The components of system interest were classified into 3 sub-models, i.e. peatlands and forest system, system of biomass accumulation and carbon stored, and productivity and economic value. First sub-model describes forest dynamics on various peat thicknesses. Peat forest cover with a total area of $68,572.99$ ha were divided into deeper peat forest (> $3 \mathrm{~m})$ covering an area of 10,234.55 ha (14.93\%) and shallow moderate depth peat forests (1-3 m) area of $58,338.44$ ha $(85.07 \%)$. Land degradation with a total of 33897.26 ha were found on deeper peatlands of 5,221.54 ha $(15.40 \%)$ and shallow moderate depth of $33,897.26$ ha $(84.60 \%)$. Rate of forest degradation during period 2003-2013 reached $3.58 \%$ year ${ }^{-1}$ on shallow moderate depth and $2.06 \%$ year $^{-1}$ on deeper peatlands. While rate of land conversion for agriculture plantation reached $0.4 \%$ year $^{-1}$. Inter-relationships between these components were

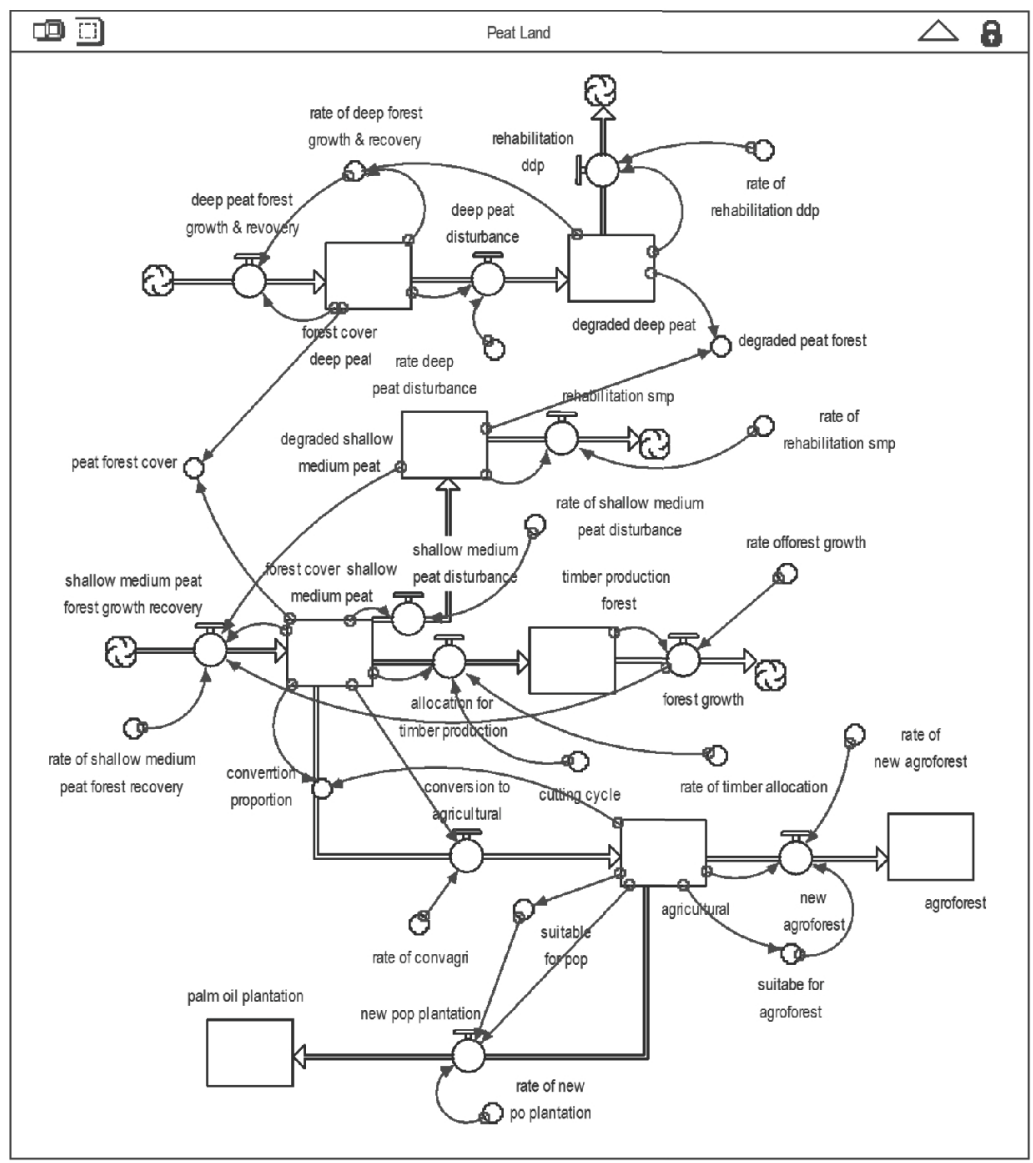

Figure 3 Model specification of system dynamics on peat land and forest. 
quantified as Figure 3. Peatland forest cover dynamics influenced by the intensity of disturbance and forest growth. Forest disturbances include forest conversion and deforestation due to encroachments and fires. This land changes were also affected by the conversion rate and the proportion of suitable land for agricultural and plantations development. In contrast with degradation, forest cover was increased as a result by logged forest growth, succession, and rehabilitation of degraded peatlands (Wösten et al. 2008; Gunawan et al.2012).

Sub model of biomass accumulation and carbon storage describe dynamics of biomass accumulation, carbon storage in soil, peat forest, and other peatland covers. Biomass accumulation is result of vegetation growth in peat forests and restoration of degraded lands (Wösten et al. 2008; Gunawan et al. 2012; Hommeltenberg et al. 2014). The ecosystem carbon storage is carbon content in vegetation biomass and carbon accumulation as result of litter decomposition. Carbon contents of peatland were determined based on average level of decomposition, levels of carbon, and land area (Wahyunto et al. 2005). The highest soil carbon is stored in primary peat forest by 3,929 ton $\mathrm{C}$ $\mathrm{ha}^{-1}$, followed by agroforestry and secondary peat forest of 3,713 and 3,612 ton $\mathrm{C} \mathrm{ha}^{-1}$, respectively. Oil palm plantations store 3,232 ton $\mathrm{Cha}^{-1}$. The lowest is in brush of 3,098 ton C $\mathrm{ha}^{-1}$. Onrizal (2010) reported that carbon content of the soil in the Singkil Swamp Wildlife Reserve in range of 496.54 to 2,587.86 ton $\mathrm{C} \mathrm{ha}{ }^{-1}$. Carbon stock in primary peat forest vegetation reached 154.12 ton ha ${ }^{-1}$ or a total 4083.12 ton ha ${ }^{-1}$ including soil carbon. Secondary peat forest stored 43.00 ton $\mathrm{C} \mathrm{ha}^{-1}$, followed by oil palm plantation and agroforestry reached 33.59 and 31.80 ton $\mathrm{C}$ ha, respectively. Shrub vegetation just saved 6.82 ton $\mathrm{ha}^{-1}$ of carbon. While Onrizal (2010) reported average of carbon stock in peat forest vegetation is 87.69 ton of $\mathrm{C} \mathrm{ha}^{-1}$. Carbon dynamics were influenced by accumulation of biomass and amount of

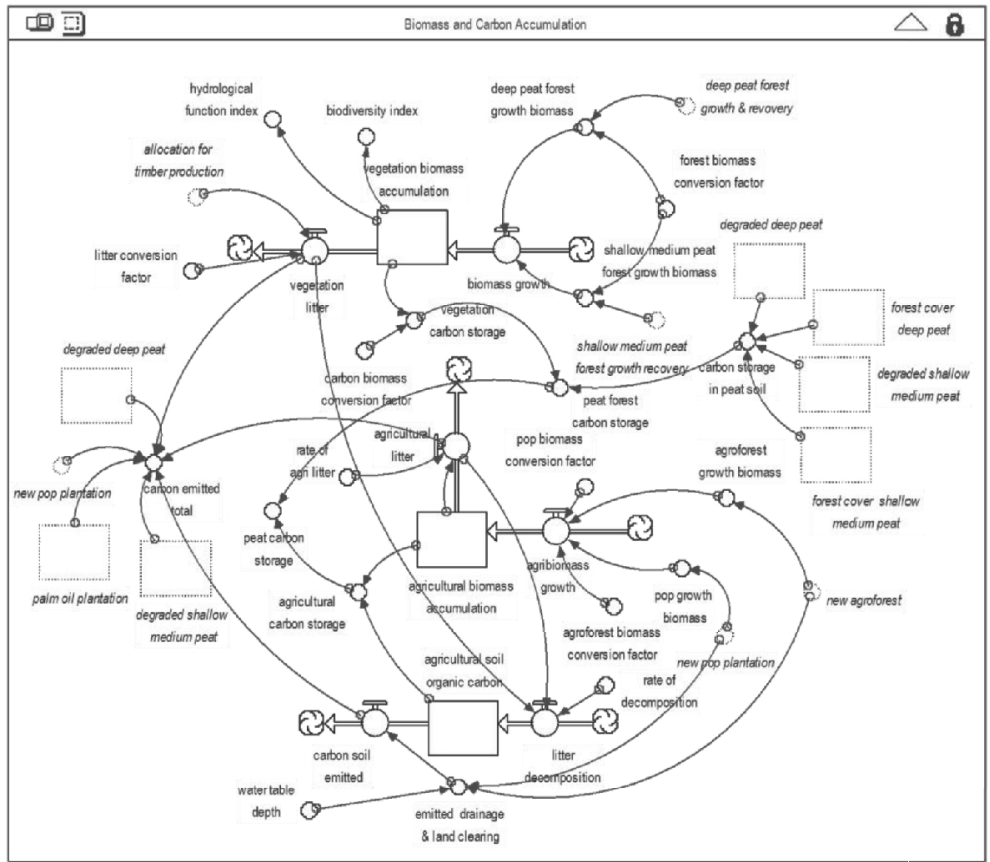

Figure 4 Model specification of system dynamic on biomass accumulation and carbon storage on peat forest and land.

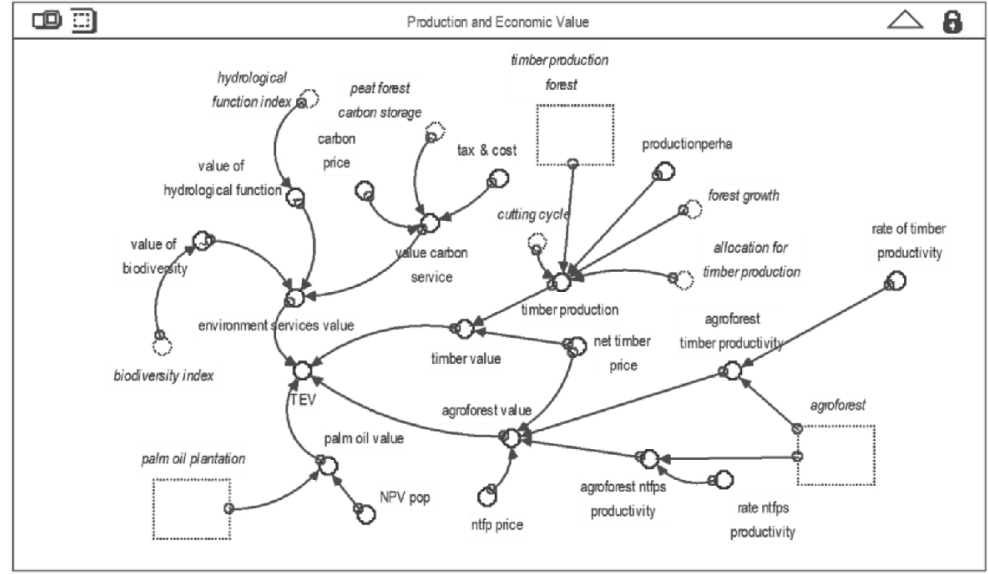

Figure 5 Model specification of productivity and forest resources economic valuation. 
carbon emitted. While carbon emissions were influenced by rate of land and forest clearance and decomposition rate of organic matter. Primary peat forest conversion and land clearing for plantations were eliminated 817.53 ton ha ${ }^{-1}$ carbon stored in vegetation. Carbon fixation 33.59 ton $\mathrm{C} \mathrm{ha}^{-1}$ in biomass of oil palm plantations is not enough to cover this loss. The highest soil carbon loss was in bushes 44.99 ton ha $^{-1}$ year $^{-1}$. Deforestation of peat primary forest into scrub was removed average 978.30 ton $\mathrm{C} \mathrm{ha}^{-1}$. Inter-relationships between these components were quantified as Figure 4.

The value of peat forest resources consist of direct use values, environmental services and biodiversity benefits. Direct use values such as extractive utilization of timber and non-timber forest products, plantation, agricultures and fisheries value were appraised by market prices. One of nontimber forest products is honey bees. Direct use values of these based on the market price is IDR 180 million year $^{-1}$. Net present value (NPV) of oil palm plantations is IDR2.895 million ha $^{-1}$ year $^{-1}$ (Buttler \& Conway 2007). Direct use values of agricultural and fishery on peatland based on market prices is IDR36 billion year ${ }^{-1}$ (Rijksen et al. 1997).

Environmental service benefits in regulating hydrological function were calculated from the cost of lost revenues (Engel et al. 2008). The benefit of carbon storage of peat protection activities were appraised based on carbon credit scheme. Cost of management was calculated $10 \%$, taxes $7 \%$ and carbon price USD3.5 ton $^{-1}$ (Buttler \& Conway 2007; Guzick \& Robinson 2013). Biodiversity benefits were calculated as value of existence which appraised using contingency approach with willingness to pay for protection of these resources. Existence value of peat ecosystem biodiversity in Trumon and Singkil reached IDR1.08 trillion year $^{-1}$ (Rijksen et al. 1997). Inter-relationships of these components were quantified as Figure 5.

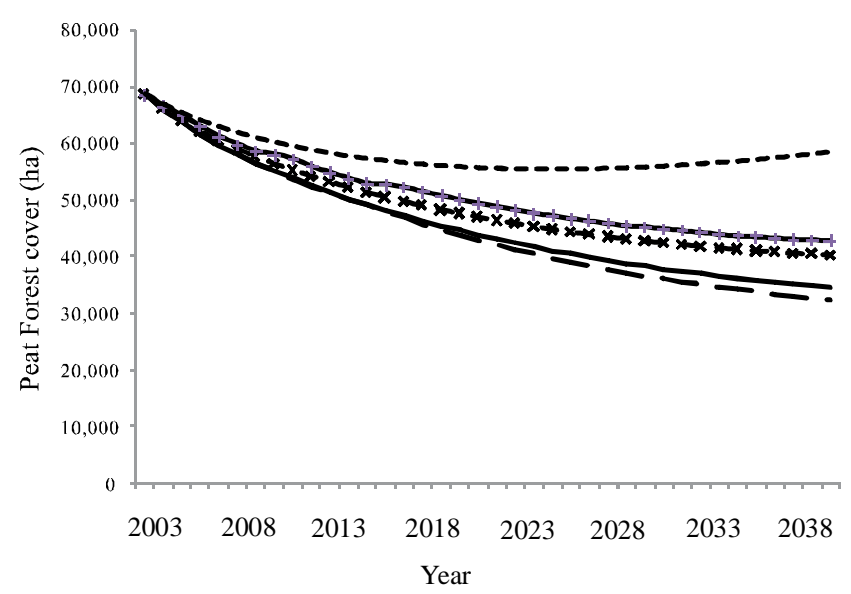

Figure 6 Projection of peat forest cover under various management policy options. Policy \#1 (baseline) $(-)$, policy\#2 (-- $)$, policy\#3 $(--*-)$, policy \#4 $(-)$, policy\#5 (----.).
Projection of policy options Model was executed by changing model equations to create various management scenarios. Forest resource allocations were determined by analyzing rate of emission reduction, direct use values and protection of biodiversity and hydrological function values. The model simulated with five management scenarios with length of simulation from year 2003 to 2040.

The $1^{\text {st }}$ scenario ran at similar rate and conditions in the last 12 years. The projection next 30 years based on current conditions showed unsustainable peat forest management. These were shown by declining of peat forest cover projection (Figure 6). Compared with year 2015, peat forest cover in 2040 would reduce to $33.99 \%$ (Table 1 ). Conversion into oil palm plantations and forest encroachment induced the forests and peatlands cover reduction. Changes on peatland cover affect benefits and functions of wetland ecosystem (Blumenfeld et al. 2009; Gunawan et al. 2012). Figure 7 and Figure 8 showed ecosystem benefits depression in carbon storage, and increasing carbon emission, conversely. Although economic benefits of oil palm plantation expansion and agroforestry practices were increased, these benefits under this policy option unable to reduce total economic value depression as a consequent of forest degradation (Table 2).

The $2^{\text {nd }}$ scenario where was executed with option to improve the short term economic benefits by converting shallow moderate depth peat into oil palm plantations at rate twice of current conditions. This policy would raise economic benefit of plantation, but total economic value decline in long term. Deforestation would reduce total economic and biodiversity values at level $-19.63 \%$ and -26.28 from current conditions. Carbon emissions were increased at 117.32 ton $\mathrm{CO}_{2} \mathrm{eq} \mathrm{ha}^{-1}$ year $^{-1}$, higher than average of carbon losses from peatland oxidation (Hooijer et al. 2010).

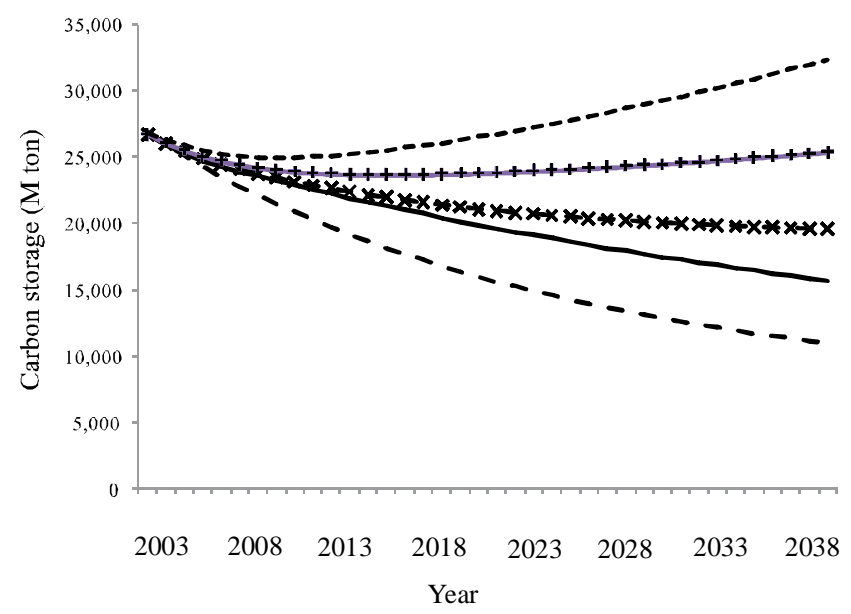

Figure 7 Projection of carbon storage in peat forest ecosystem under various management policy options. Policy \#1 (baseline) $(\longrightarrow$, policy \#2(---), policy\#3 (--*-), policy\#4 (-), policy\#5 (------). 
Table 1 Projection of peat forest cover, carbon storage and emitted based on various policy options

\begin{tabular}{|c|c|c|c|c|c|c|c|c|}
\hline \multirow{3}{*}{ Policy option } & \multicolumn{4}{|c|}{ Peat land cover } & \multicolumn{3}{|c|}{ Carbon storage dynamics } & \multirow{3}{*}{$\begin{array}{c}\text { C emitted } \\
\left(\mathrm{CO}_{2} \text { eq ton ha }\right. \\
\left.\text { year }{ }^{-1}\right)\end{array}$} \\
\hline & \multicolumn{2}{|c|}{ Forest } & \multicolumn{2}{|c|}{ Non-forest* } & \multirow{2}{*}{$\begin{array}{c}\text { Ecosystem } \\
\text { (M ton) }\end{array}$} & \multirow{2}{*}{$\begin{array}{l}\text { Forest } \\
\text { (M ton) }\end{array}$} & \multirow{2}{*}{$\begin{array}{c}\mathrm{C} \text { emitted } \\
\left(\mathrm{CO}_{2} \mathrm{M} \text { ton }\right. \\
\left.\text { year }^{-1}\right)\end{array}$} & \\
\hline & (ha) & $(\%)$ & (ha) & $(\%)$ & & & & \\
\hline 2015 & 49,011 & 44.24 & 61,775 & 55.76 & $22,780.28$ & $19,120.12$ & $1,735.90$ & 35.42 \\
\hline \multirow[t]{2}{*}{ Policy $1^{\text {st }}$} & 32,352 & 29.20 & 78,434 & 70.80 & $13,693.24$ & $18,598.03$ & $2,398.13$ & 74.13 \\
\hline & - (33.99) & & (+) 26.97 & & $-(39.89)$ & $-(2.73)$ & (+) 38.15 & \\
\hline \multirow[t]{2}{*}{ Policy $2^{\text {nd }}$} & 29,974 & 27.06 & 80,812 & 72.94 & $9,351.40$ & $18,326.17$ & $3,516.53$ & 117.32 \\
\hline & - (38.84) & & (+) 30.82 & & $-(58.95)$ & $-(4.15)$ & ${ }^{(+)} 102.58$ & \\
\hline \multirow[t]{2}{*}{ Policy $3^{\text {th }}$} & 39,199 & 35.38 & 71,587 & 64.62 & $19,263.14$ & $20,167.94$ & $2,881.23$ & 73.50 \\
\hline & - (20.02) & & (+) 15.88 & & $-(15.44)$ & (+) 5.48 & ${ }^{(+)} 65.98$ & \\
\hline \multirow[t]{2}{*}{ Policy $4^{\text {th }}$} & 40,118 & 36.21 & 70,668 & 63.79 & $26,636.61$ & $21,999.64$ & $1,615.14$ & 40.26 \\
\hline & - (18.14) & & (+) 14.40 & & ${ }^{(+)} 16.93$ & (+) 15.06 & $-(6.96)$ & \\
\hline \multirow[t]{2}{*}{ Policy $5^{\text {th }}$} & 62,761 & 56.65 & 48,025 & 43.35 & $36,429.27$ & $31,226.66$ & $1,127.32$ & 17.96 \\
\hline & (+) 28.05 & & $-(22.26)$ & & (+) 59.92 & (+) 63.32 & $-(35.06)$ & \\
\hline
\end{tabular}

Non-forest* consist of agricultural land, oil palm plantation and agroforestry

Policy $1^{\text {st }}$. Projection on current condition

Policy $2^{\text {nd }}$. Projection based on scenario convert swallow-moderate depth peatlands to agriculture

Policy $3^{\text {th }}$. Projection based on scenario $25 \%$ peat forest cover protection

Policy $4^{\text {th }}$. Projection of peat forest cover, total economic value, oil palm plantation value, carbon emitted, and carbon storage based on scenario $50 \%$ peat forest cover protection and agroforestry development

Policy $5^{\text {th }}$. Projection based on scenario peat forest moratorium and followed by degraded peatland rehabilitation and agroforestry development

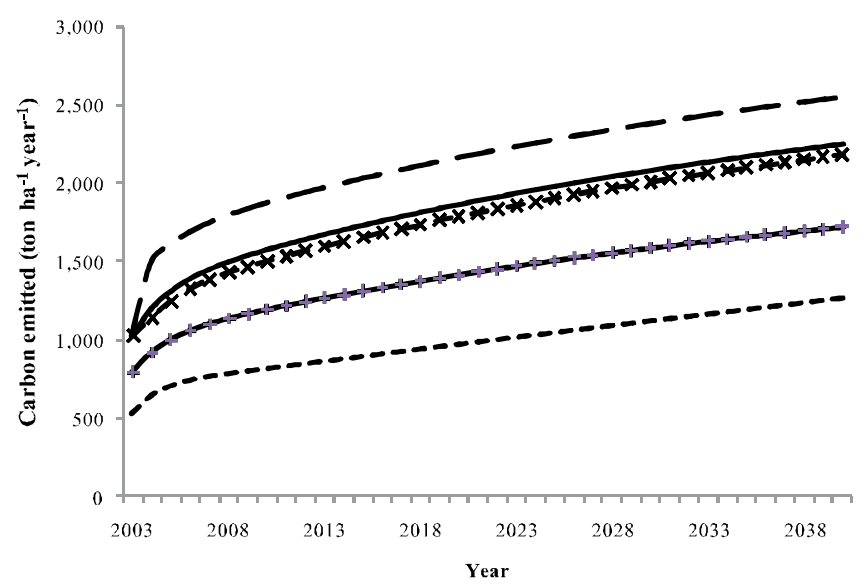

Figure 8 Projection of carbon emitted from peat forest ecosystem under various management policy options. Policy \#1 (baseline) ( - ), policy \#2 $(--\cdot)$, policy\#3 (--), policy\#4 (-), policy\#5 $(----)$.

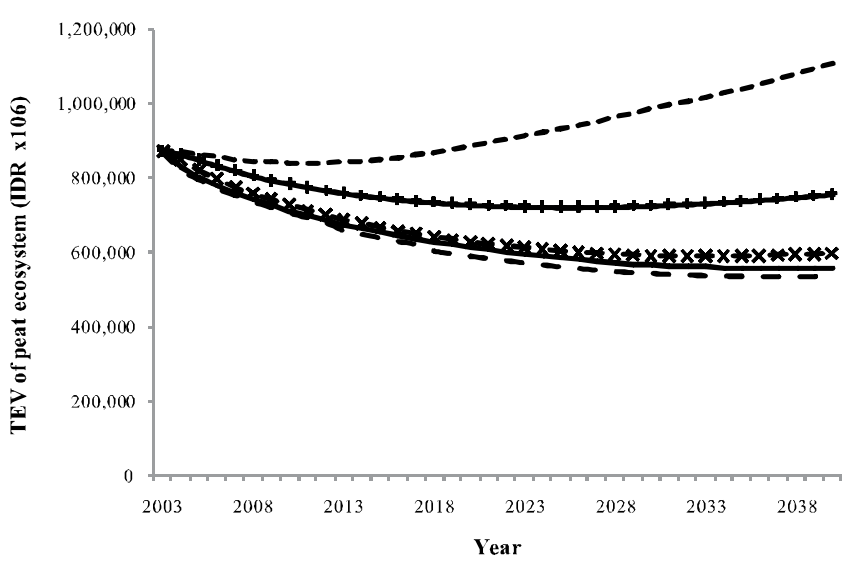

Figure 9 Projection total economic value of peat forest ecosystem under various management policy options. Policy \#1 (baseline) ( - ), policy \#2 $(---)$, policy\#3 (-*-), policy\#4 $(\rightarrow)$, policy\#5 (----). 
Table 2 Projection of total economic value on peat forest ecosystem based on various policy options

\begin{tabular}{|c|c|c|c|c|c|c|c|}
\hline \multirow[b]{2}{*}{ Policy option } & \multirow{2}{*}{$\begin{array}{c}\text { Total } \\
\text { economic } \\
\text { value }\end{array}$} & \multicolumn{3}{|c|}{ Extractive direct use benefits } & \multicolumn{2}{|c|}{ Environmental benefits } & \multirow[b]{2}{*}{$\begin{array}{c}\text { Biodiversity } \\
\text { value }\end{array}$} \\
\hline & & Timber & $\begin{array}{l}\text { Oil palm } \\
\text { plantation }\end{array}$ & Agroforestry & $\begin{array}{l}\text { Carbon } \\
\text { storage }\end{array}$ & $\begin{array}{l}\text { Hydrological } \\
\text { function }\end{array}$ & \\
\hline 2015 & 664,310 & 60,863 & 2,040 & 52,664 & 2,969 & 956 & 544,818 \\
\hline \multirow[t]{2}{*}{ Policy 1 st } & 587,139 & 52,386 & 3,112 & 61,258 & 3,211 & 930 & 466,242 \\
\hline & - (11.62) & - (13.93) & $(+)_{52.55}$ & $(+)_{16.32}$ & $-(8.15)$ & $-(2.72)$ & - (14.42) \\
\hline \multirow[t]{2}{*}{ Policy $2^{\text {nd }}$} & 533,907 & 55,761 & 3,876 & 68,307 & 3,409 & 916 & 401,638 \\
\hline & - (19.63) & $-(8.38)$ & $(+)_{90.00}$ & $(+)_{29.70}$ & $-(14.82)$ & $-(4.18)$ & $-(26.28)$ \\
\hline \multirow[t]{2}{*}{ Policy $3^{\text {th }}$} & 618,439 & 52,967 & 2,030 & 61,258 & 3,201 & 1,008 & 497,975 \\
\hline & $-(6.91)$ & $-(12.97)$ & - (0.49) & $(+) 16.32$ & $-(7.81)$ & $(+)_{5.44}$ & $-(8.60)$ \\
\hline \multirow[t]{2}{*}{ Policy $4^{\text {th }}$} & 819,115 & 75,271 & 1,332 & 61,149 & 3,211 & 1,100 & 677,052 \\
\hline & $(+)_{23.30}$ & $(+)_{23.67}$ & $-(34.71)$ & $(+)_{16.11}$ & $(+)_{8.15}$ & $(+)_{15.06}$ & $(+)_{24.27}$ \\
\hline \multirow[t]{2}{*}{ Policy $5^{\text {th }}$} & $1,144,053$ & 107,109 & 2,896 & 53,623 & 3,839 & 1,561 & 975,025 \\
\hline & $(+)_{72.22}$ & $(+)_{75.98}$ & $(+)_{41.96}$ & $(+)_{1.82}$ & $(+)_{29.30}$ & $(+)_{63.28}$ & $(+)_{78.96}$ \\
\hline
\end{tabular}

economic value $=$ value $000.000,-($ IDR $)$

The $3^{\text {rd }}$ scenario was executed with preserving $25 \%$ of forest cover on shallow moderate depth peat and convert its remaining to agricultural plantation. The projection showed that these policies insufficient to reduce level of carbon emitted from forest and land degradation. Carbon emission reached 73.50 ton $\mathrm{CO}_{2}$ eq $^{-1}$ year $^{-1}$ or increased $65.98 \%$ from current condition. These level still higher (Hooijer et al. 2010). As a consequence, total economic value of ecosystem benefits would decline in long term (Figure 9). Compared than year 2015, peat forest cover in year 2040 would decrease to $20.02 \%$.

Similar to the $3^{\text {rd }}$, the $4^{\text {th }}$ scenario was executed by protecting a half $(50 \%)$ forest cover on shallow-moderate depth peat, followed by agroforestry development on degraded peatlands. It is necessary to preserve peatland forests function as a hidrology unitary. Referring to $2^{\text {nd }}$ scenario, although forest cover has reserved $25 \%$, it is not enough to overcome rate of emissions and environmental service benefits declining in the long term. The projection is showed that the $4^{\text {th }}$ policy would reduce rate of forest cover degradation on peat, although the remaining forest area still narrow $(18.14 \%$ ) (Table 1$)$. This reduction would decrease the level of carbon emitted in year 2040 at 40.26 ton $\mathrm{CO}_{2}$ eq $\mathrm{ha}^{-1}$ year $^{-1}$ or $-6.96 \%$ from current condition, and enhance forest carbon storage up to $15.06 \%$. This emission is lower than average of oxidation level from tropical peatland drainaged which reached 65 ton $\mathrm{CO}_{2}$ eq ha $^{-1}$ year ${ }^{-1}$ (Hooijer et al. 2010). Increasing proportion of peat forest cover would enhance the benefits of hydrological function and biodiversity (Dommain et al. 2010; Onrizal et al. 2010) while providing short-term benefits of agroforestry practices. These schemes escalate total economic value of ecosystem (Figure 9).
The $5^{\text {th }}$ policy scenarios ran with moratorium (suspending) primary peat forest clearance and followed by degraded peat forest rehabilitation with agroforestry development and oil palm plantations. This policy would increase peat forest cover up to $28.05 \%$ of current conditions. This scheme also reduce rate of carbon emission $(-35.06 \%)$ and increase forest carbon storage at significant rate $(+63.32 \%)$. Increasing proportion of peat forest cover through moratorium of primary peat forest clearance and rehabilitation of degraded peatland enhance benefits of hydrological functions and biodiversity up to $63.28 \%$ and $78.96 \%$, respectively (Table 2 ). Preservation the peatlands for their carbon value would generate income from carbon credits market. A study done in Central Kalimantan indicate that value of carbon credit from a 1,000 ha area would be worth USD6.32-9.02 million, which would be greater than net income from a oil palm plantation (Hemanath \& Tisdell 2009). Butler and Conway (2007) demonstrated that this mitigation scheme is more economically profitable than using the land to produce palm oil.

Allocation and policy implication Forest and peatland management policies at various intensities provide diversity on economic and environmental services benefits. Efforts to generate short-term benefits by changing peat forest function will enhance higher direct economic value, but deflate their environmental benefits. First policy option projection showed that peat forest management on current condition would not fulfill the principles of sustainability. Even though concession benefits were higher, utilization of ecosystems provide lower economic value for community. Environmental services in regulation of hydrological 
function and biodiversity protection would decline in long term. Increasing intensity and economic losses due to floods are indications of ecosystem function degradation (Blumenfeld et al. 2009; Dommain et al. 2010). The $4^{\text {th }}$ and $5^{\text {th }}$ scenarios allowed maximum environmental services benefits, but the latter were more take side for community. Both of schemes support the Presidential Instruction Number $6 / 2013$ on moratorium or suspension on granting of new licenses and improvement of natural primary forest and peatland governance and the United Nations' program on Reducing Emissions from Deforestation and Forest Degradation in developing countries (REDD). This program is being intensively discussed as a key framework in international conventions on climate change (Stern 2006).

The opportunities from non-timber forest products and agroforestry development on degraded peatlands will escalate community welfare. Community involvement in restoring ecosystem function would diminish their dependence on forest-damaging practices (Keenleyside et al. 2012). Rehabilitation of degraded peatland with agroforestry and oil palm plantations and preservation the peatlands for carbon trading would generate income from operation of concession, non-timber forest product harvesting for community welfare, and revenue from carbon market.

The results showed that current forests and peatlands management are must be reorganized, particularly in planning and monitoring conditions in long-term. Forest criticality assessment which applied the Regulation of Minister of Forestry (Permenhut) Number P.32/2009 revised Permenhut P.12/2012 need to be improved by considering criteria and indicator impacts, so that its application in peat swamp forests more appropriate. Peat ecosystem should be managed as a holistic hydrological systems management. Collaborative management schemes are indispensable for multiple stakeholders involved such as Watershed Management Agency (BPDAS) of Wampu Ular, Gunung Leuser National Park (TNGL), Forestry and Plantation Services (Dinas Kehutanan dan Perkebunan), local government and plantation companies. Considering peat utilization as multiple benefits management, clarity of roles and responsibilities of each party are indispensable. Simulations based on dynamics of the system can be used to determine impact of certain policy as long-term consequences of system interest.

Peatland ecosystems is proposed as a protected area or adaptive management and intensive, with consideration the criticality criteria and their physiological characteristics (Aswandi et al. 2015). Peat dome and very deep peatlands should be protected and rehabilitated when degraded. If the right policies and institutional structures were in place, preventing further deforestation would be cheaper than other types of mitigation strategies for greenhouse gas emissions (Stern 2006). Adaptive management allowed on uncritical edge shallow peat to moderate depth only with water table regulation. Meanwhile, intensive management is permitted in very shallow peat and uncritically edge peat. Various alternative designations of forest and peatland are showed in Table 4.

Adaptive management is conducted for limited timber production limited with selective logging and potential NTFPs development such as aloes, rattan, honey, and bark. Agroforestry patterns are developed without much changing forest cover to reduce malfunctioning of hydrology and biodiversity. Water level regulation is a requirement. The water level should not be deeper than $60 \mathrm{~cm}$ in drained peatlands (Aswandi et al. 2015). Excessive drainage would dry out the peat thus changing its characteristics, peat becomes vulnerable to fire and unable to absorb water. The escalation of flooding intensity and smog hazard from peat fires are evidence of these changes (Holden et al. 2004; Erwin 2008; Hooijer et al. 2010). Intensive management is allowed by maintaining forest cover at least $50 \%$. Management schemes such as timber production with selective logging, plantations and agricultural development proportionally. Opportunities of NTFPs management and agroforestry development on degraded land would improve the community welfare and reduce the dependence on forestdamaging practices indirectly.

Understanding of processes and impacts of policy options on the system dynamic are important factors in utilizing the model as a learning tool (Sterman 2001; Purnomo \& Mendoza 2011; Mousavi \& Sadeghian 2015). If the processes could be understood, built model would improve the capabilities of policy-makers to set proper policy options and make the right decisions to increase community welfare and reduce forest degradation.

Table 3 Economic and environmental services benefit based on various peatlands management policy

\begin{tabular}{|c|c|c|c|c|c|c|c|c|}
\hline \multirow{2}{*}{ Policy option } & \multirow{2}{*}{$\begin{array}{c}\text { Community } \\
\text { income }\end{array}$} & \multicolumn{2}{|c|}{ Government income } & \multirow{2}{*}{$\begin{array}{c}\text { Concession } \\
\text { income }\end{array}$} & \multirow{2}{*}{$\begin{array}{c}\text { Biomass } \\
\text { accumulation }\end{array}$} & \multirow{2}{*}{$\begin{array}{l}\text { Carbon } \\
\text { emitted }\end{array}$} & \multirow{2}{*}{$\begin{array}{c}\text { Hydrological } \\
\text { function }\end{array}$} & \multirow{2}{*}{ Biodiversity } \\
\hline & & Local & Central & & & & & \\
\hline Policy $1^{\text {st }}$ & Low & Low & Low & High & Low & High & Low & Low \\
\hline Policy $2^{\text {nd }}$ & Low & Higher & Higher & Higher & Lower & Higher & Lower & Lower \\
\hline Policy $3^{\text {th }}$ & Low & Lower & Lower & Lower & Higher & Lower & Lower & Lower \\
\hline Policy $4^{\text {th }}$ & High & Lower & Lower & Lower & Higher & Lower & Higher & Higher \\
\hline Policy $5^{\text {th }}$ & High & Higher & Higher & Higher & Higher & Lower & Higher & Higher \\
\hline
\end{tabular}


Table 4. Criteria and alternatives sustainable allocation of peat forest ecosystem

\begin{tabular}{|c|c|c|c|c|}
\hline Depth & Physiology & Criticality & Allocation & Management strategy \\
\hline \multirow[t]{4}{*}{$\begin{array}{l}\text { Very deep-deep } \\
(>3 \mathrm{~m})\end{array}$} & \multirow[t]{2}{*}{ Peat dome } & Critical & Protection & $\begin{array}{l}\text { Restoration with endemic and non-invasive species, } \\
\text { protection/conservation }\end{array}$ \\
\hline & & $\begin{array}{l}\text { Not } \\
\text { disturbed }\end{array}$ & Prot ection & Protection/conservation \\
\hline & \multirow[t]{2}{*}{ Peat edge } & Critical & Protection & $\begin{array}{l}\text { Restoration with endemic and non-invasive species, } \\
\text { protection/conservation }\end{array}$ \\
\hline & & $\begin{array}{l}\text { Not } \\
\text { disturbed }\end{array}$ & Protection & Protection/conservation \\
\hline \multirow{4}{*}{$\begin{array}{l}\text { Moderate } \\
(1-3 \mathrm{~m})\end{array}$} & \multirow[t]{2}{*}{ Peat dome } & Critical & Protection & Restoration with endemic species, protection/conservation \\
\hline & & $\begin{array}{l}\text { Not } \\
\text { disturbed }\end{array}$ & Protection & Protection/conservation \\
\hline & \multirow[t]{2}{*}{ Peat edge } & Critical & $\begin{array}{l}\text { Adaptive } \\
\text { management }\end{array}$ & $\begin{array}{l}\text { Rehabilitation with endemic and non-invasive species/ } \\
\text { protection } 50 \% \text { forested area }\end{array}$ \\
\hline & & $\begin{array}{l}\text { Not } \\
\text { disturbed }\end{array}$ & $\begin{array}{l}\text { Adaptive } \\
\text { management }\end{array}$ & $\begin{array}{l}\text { Limited production (selective logging), plantation with } \\
\text { water table management and protection } 50 \% \text { forested area }\end{array}$ \\
\hline \multirow[t]{4}{*}{$\begin{array}{l}\text { Shallow } \\
(0.5-1 \mathrm{~m})\end{array}$} & \multirow[t]{2}{*}{ Peat dome } & Critical & $\begin{array}{l}\text { Adaptive } \\
\text { management }\end{array}$ & $\begin{array}{l}\text { Rehabilitation using non-invasive species, limited } \\
\text { production (selective logging), plantation with water table } \\
\text { management, and protection } 50 \% \text { forested area }\end{array}$ \\
\hline & & $\begin{array}{l}\text { Not } \\
\text { disturbed }\end{array}$ & $\begin{array}{l}\text { Adaptive } \\
\text { management }\end{array}$ & $\begin{array}{l}\text { Limited production (selective logging), plantation with } \\
\text { water table management, and protection } 50 \% \text { forested area }\end{array}$ \\
\hline & \multirow[t]{2}{*}{ Peat edge } & Critical & $\begin{array}{l}\text { Adaptive } \\
\text { management }\end{array}$ & $\begin{array}{l}\text { Rehabilitation using non-invasive species, limited } \\
\text { production (selective logging), plantation with water table } \\
\text { management, and protection } 50 \% \text { forested area }\end{array}$ \\
\hline & & $\begin{array}{l}\text { Not } \\
\text { disturbed }\end{array}$ & $\begin{array}{l}\text { Intensive } \\
\text { management }\end{array}$ & $\begin{array}{l}\text { Limited production (selective logging), plantation with } \\
\text { water management, and protection } 50 \% \text { forested area }\end{array}$ \\
\hline \multirow[t]{4}{*}{ Very shallow $(<0.5 \mathrm{~m})$} & \multirow[t]{2}{*}{ Upstream peat } & Critical & $\begin{array}{l}\text { Intensive } \\
\text { management }\end{array}$ & $\begin{array}{l}\text { Rehabilitation using non-invasive species, timber } \\
\text { production (clear cutting and pulp plantation), } \\
\text { agroforestry development }\end{array}$ \\
\hline & & $\begin{array}{l}\text { Not } \\
\text { disturbed }\end{array}$ & $\begin{array}{l}\text { Intensive } \\
\text { management }\end{array}$ & $\begin{array}{l}\text { Timber production (clear cutting and pulp plantation), } \\
\text { agricultural/plantation, agroforestry development }\end{array}$ \\
\hline & \multirow[t]{2}{*}{ Peat edge } & Critical & $\begin{array}{l}\text { Intensive } \\
\text { management }\end{array}$ & $\begin{array}{l}\text { Rehabilitation using non-invasive species, intensive } \\
\text { production (clear cutting and pulp plantation), plantation, } \\
\text { agricultural and agroforestry development }\end{array}$ \\
\hline & & $\begin{array}{l}\text { Not } \\
\text { disturbed }\end{array}$ & $\begin{array}{l}\text { Intensive } \\
\text { management }\end{array}$ & $\begin{array}{l}\text { Timber production (clear cutting and pulp plantation), } \\
\text { intensive production, plantation, agricultural and } \\
\text { agroforestry development }\end{array}$ \\
\hline
\end{tabular}

List Abbreviation:

BPDAS: Balai Pengelolaan Daerah Aliran Sungai, BPKH: Balai Pemantapan Kawasan Hutan, GHGs: Greenhouse gases, IDR: Indonesian Rupiah MoF: Ministry of Forestry, NTFPs: Non-timber forest products, OPP: Oil palm plantation, REDD: Reducing Emissions form Deforestation and Forest Degradation in developing countries, TEV: Total economic value, TNGL: Taman Nasional Gunung Leuser, USD: United State Dollar

\section{Conclusion}

The system dynamics can be used as a tool to develop various scenarios of forest management by analyzing impact of policies. Changes primary peat forest to oil palm plantation would reduce value of ecosystem benefits. Carbon emissions were increased at 117.32 ton $\mathrm{CO}_{2}$ eq ha ${ }^{-1}$ year ${ }^{-1}$, higher than average of carbon losses from peatland oxidation. Preserving 50\% of forest vegetation on moderate depth and protection very deep peatlands would reduce emission $6.96 \%$ to $-35.06 \%$ and increase forest carbon storage at significant rate $+15.06 \%$ to $+63.32 \%$, respectively. These mitigation schemes propose maximum environmental service benefits, optimum total economic value, higher ecological preservation and short-term benefits value, and favor to community development. Forest rehabilitation with agroforestry practices will enhance carbon uptake, especially on degraded lands. Model developed can be applied in determining the peat ecosystem management decisions. Understanding the process and impact of these policy choices would help policy makers to optimize the peat forest management. Validation is required when applied to similar ecosystems elsewhere. 


\section{Acknowledgments}

This research was partially supported by Forestry Research Development and Innovation, Ministry of Environment and Forestry. We thank our colleagues from Forestry Research Institute of Aek Nauli, who provided insight and expertise that greatly assisted the research. We thank Dr. Ahmad Maryudi for assistance with methodology and comments that greatly improved the manuscript.

\section{References}

Aswandi. 2007. Analytical system model of growth dynamic and yield regulation for logged-over swamp forest in Riau. Jurnal Penelitian Hutan dan Konservasi Alam 4(3):239-249.

Aswandi, Sadono R, Supriyo H, Hartono. 2015. Determinant factors of criticality and development criteria indicators for critical tropical peat ecosystem in Trumon and Singkil, Province of Aceh. Jurnal Manusia dan Lingkungan 22(3):319-325.

Basyuni M, Putri LAP, Murni MB. 2015. Implication of land-use and land-cover change into carbon dioxide emissions in Karang Gading and Langkat Timur Wildlife Reserve, North Sumatra, Indonesia. Jurnal Manajemen Hutan Tropika 21(1):25-35. http://dx.doi.org/10.7226/ jtfm.21.1.25.

Blumenfeld S, Lu C, Christophersen T, Coates D. 2009. Water, Wetlands and Forests. A Review of Ecological, Economic and Policy Linkages. CBD Technical Series No. 47. Secretariat of the Convention on Biological Diversity and Secretariat of the Ramsar Convention on Wetlands: Montreal.

BPKH II Medan. 2014. Database peta penutupan hutan DAS Singkil tahun 2003, 2009 dan 2011. Data dalam bentuk ext.shp. Balai Pemantapan Kawasan Hutan Wilayah II Medan. Medan: Direktorat Jenderal Planologi Kehutanan Kementerian Kehutanan.

Butler RA, Conway S. 2007. Could peatlands conservation be more profitable than palm oil? http://news.mongabay. com/2007/08/could-peatlands-conservation-be-moreprofitable-than-palm-oil/ [22 August 2014].

Carson RT. 2011. Contingent valuation: a comprehensive bibliography and history. Massachusset. USA: Edward Elgar Publishing. http://dx.doi.org/10.4337/9780857 936288.

Conservation International, Departemen Kehutanan, LIPI, Universitas Andalas, Universitas Syiah Kuala, \& Wildlife Conservation Society. 2007. Priority sites for conservation in Sumatra: key biodiversity areas. . Jakarta: CII, Dephut, LIPI, Unand, Unsyiah, WCS.

Dommain R, Couwenberg J, Joosten H. 2010. Hydrological self-regulation of domed peatlands in south-east asia and consequences for conservation and restoration. Mires and Peat 6(5):1-17.

Engel S, Pagiola S, Wunder S. 2008. Designing payments for environmental services in theory and practice: an overview of the issues. Ecological Economics 65:663-675. http://dx.doi.org/10.1016/j.ecolecon. 2008.03.011.

Erwin KL. 2008. Wetlands and global climate change: the role of wetland restoration in a changing world. Wetlands Ecology and Management 17(1):71-84. http://dx.doi. org/10.1007/s11273-008-9119-1.

Forest Watch Indonesia. 2011. Potret Keadaan Hutan Indonesia Periode 2000-2009. Bogor: Forest Watch Indonesia.

Ghaffarzadegan N, Lyneis J, Richardson GP. 2011. How small system dynamics models can help the public policy process. System Dynamics Review 27(1):22-44.

Grant JW, Pedersen EK, Marin SL. 1997. Ecology and natural resource management: system analysis and simulation. New York: Addison-Wesley Publishing Co.

Gronlund A, Atle H, Anders H, Daniel PR. 2008. Carbon loss estimates from cultivated peat soils in Norway: a comparison of three methods. Nutrient Cycling in Agroecosystems 81:157-167. http://dx.doi.org/10.1007/ s10705-008-9171-5.

Gunawan H, Kobayashi S, Mizuno K, Kono Y. 2012. Peat swamp forest types and their regeneration in Giam Siak Kecil-Bukit Batu Biosphere Reserve, Riau, East Sumatra, Indonesia. Mires and Peat 10(5):1-17.

Guzick S, Robinson N. 2013. The implementation limitations of and alternative policy solutions for indonesia's REDD+ program concerning peatland restoration. International Journal of Rural Law and Policy. Special Edition.

Hemanath SN, Tisdell C. 2009. The orangutan-oil palm conflict: economic constraints and opportunities for conservation. Biodiversity Conservation 18(496).

Hirano T, Kusin K, Limin S, Osaki M. 2014. Carbon dioxide emissions through oxidative peat decomposition on a burnt tropical peatland. Global Change Biologi 20(2):555-565. http://dx.doi.org/10.1111/gcb.12296.

Holden J, Chapman PJ, Labads JC. 2004. Artificial drainage of peatlands: hydrological and hydrochemical process and wetland restoration. Physical Geography 28(1):95-123. http://dx.doi.org/10.1191/0309133304p p403ra.

Hommeltenberg J, Schmid HP, Drösler M, Werle P. 2014. Can a bog drained for forestry be a stronger carbon sink than a natural bog forest? Biogeosciences 11:3477-3493. http://dx.doi.org/10.5194/bg-11-3477-2014. 
Hooijer A, Page S, Canadell JG, Silvius M, Kwadijk J, Wosten H, Jauhiainen J. 2010. Current and future $\mathrm{CO}_{2}$ emissions from drained peatlands in Southeast Asia. Biogeosciences 7:1505-1514. http://dx.doi.org/10.5194/ bg-7-1505-2010.

Keenleyside KA, Dudley N, Cairns S, Hall CM, Stolton S. 2012. Ecological Restoration for Protected Areas: Principles, Guidelines and Best Practices. IUCN: Gland, Switzerland.

Krisnawati H, Adinugroho WC, Imanuddin R. 2012. Modelmodel Alometrik untuk Pendugaan Biomassa Pohon pada Berbagai Tipe Ekosistem Hutan di Indonesia. Bogor: Pusat Penelitian dan Pengembangan Konservasi dan Rehabilitasi Badan Penelitian dan Pengembangan Kehutanan.

Maswar, Haridjaja O, Sabiham O, van Noordwijk M. 2011. Cadangan, kehilangan, dan akumulasi karbon pada perkebunan kelapa sawit di lahan gambut tropika. Journal of Soil and Land Utilization Management $8(1): 1-10$.

Miettinen J, Chenghua S, Liew SC. 2012. Two decades of destruction in Southeast Asia's peat swamp forests. Frontiers in Ecology and the Environment 10:124-128. http://dx.doi.org/10.1890/100236.

Mousavi Z, Sadeghian A. 2015. Analyzing Balanced Scorecard with System Dynamics. Advance Environment Biology 9(2):186-194.

Murdiyarso D, Kauffman JB, Verchot LV. 2013. Climate change mitigation strategies should include tropical wetlands. Carbon Management 4:491-499. http://dx.doi.org/10.1016/j.biocon.2011.07.015.

Onrizal, Perbatakusuma EA, Sulistiyono N. 2010. Kandungan karbon Rawa Singkil dan potensi pengembangan produk jasa lingkungan di Kabupaten Aceh Singkil dan Kota Subulussalam. Prosiding Seminar Nasional Hasil-hasil Penelitian Bidang Kehutanan dan Hasil Hutan. Medan: Universitas Sumatera Utara.

A MRC. 2011. Peat swamp forest avifauna of Central Kalimantan, Indonesia. Effects of habitat loss and degradation. Biological Conservation 144:2548-2556. http://dx.doi.org/10.1016/j.biocon.2011.07.015.
Purnomo H, Mendoza G. 2011. A system dynamics model for evaluating collaborative forest management: a case study in Indonesia, International Journal of Sustainable Development \& World Ecology 18(2):164-176. http://dx.doi.org/10.1080/13504509.2010.549664.

Rijksen HD, Diemont WH, Griffith M. 1997. The Singkil swamp: the kidneys of the Leuser ecosystem in Aceh, Sumatra, Indonesia. In: Biodiversity and Sustainability of Tropical Peatlands. Rieley JO, Page SE, editors. Cardigan: Samara Publishing.

Sterman JD. 2001.System dynamics modeling: tool for learning in a complex world. California Management Review 43(4):8-25. http://dx.doi.org/10.2307/ 41166098.

Stern N. 2006. The Stern Review on the Economics of Climate Change. HM Treasury, London, (http://webarchive.nationalarchives.gov.uk/+/http://ww w.hm-treasury.gov.uk/independent_reviews/ stern_review_economics_climate_change/stern_review _report.cfm [28 May 2013].

Sudip M, Wassmann R, Vlek PLG. 2005. An appraisal of global wetland area and its organic carbon stock. Current Science 88(1):25-35.

Wahyunto, Ritung S, Suparto, Subagjo H. 2005. Sebaran Gambut dan Kandungan Karbon Sumatera. Bogor: Wetland International-Indonesia Program and Wildlife Habitat Canada (WHC). http://www.wetlands.or.id/ PDF/buku/Atlas\%20Sebaran\%20Gambut\%20Sumatera .pdf. [24 August 2015]

Wich SA, Meijaard E, Marshall AJ, Husson S, Ancrenaz M, Lacy RC, van Schaik CP, Sugardjito J, Simorangkir T, Traylor-Holzer K, Doughty M, Supriatna J, Dennis R, Gumal M, Knott, CD, Singleton I. 2008. Distribution and conservation status of the orang-utan (Pongo spp.) on Borneo and Sumatra: how many remain? Oryx 42(3):329-339. http://dx.doi.org/10.1017/S00306053 0800197X.

Wösten JHM, Rieley JO, Page SE. 2008. Restoration of tropical peatlands. Alterra - Wageningen University and Research Centre, and the EU INCO - RESTORPEAT Partnership. http://www.biosafety.nl/upload_mm/ a/f/4/013a2161-9803-47a7-9585-a5e85072d7b9_ RestorationBook5.pdf\#page $=19$ [24 Augus 2015]. 